\title{
AN ERROR ANALYSIS OF WRITING RECOUNT TEXT BASED ON GENDER
}

\author{
Yuda Anggara1, Acep Haryudin² \\ ${ }^{1}$ IKIP Siliwangi \\ ${ }^{2}$ IKIP Siliwangi \\ ${ }^{1}$ yudaanggara@ student.ikipsiliwangi.ac.id, ${ }^{2}$ haryacep@gmail.com
}

\begin{abstract}
This research was conducted to find out how the gender perspective in the mistakes produced by students in the recount text. Students errors were analyzed using errors analysis. This research used qualitative descriptive method as the research methodology. The data would be presented descriptively and the result was in explanation of words form which would be following by data presented in form of tables. The errors made by female there are 12 errors of omission, 13 errors in addition, 21 errors in misformation and 1 errors in misordering. while the errors are made by male there are 5 errors of omission, 5 errors in addition, 27 errors in misformation and 1 errors in misordering. The instrument in this research was a test item created by students. From this research it can be deduced that the most mistakes made by female and male are errors in the way of misformation because students lack understanding of how to make stories in the writing recount text.
\end{abstract}

Keywords: Writing, Error Analysis, Recount Text

\section{INTRODUCTION}

One of the basic skills of 4 basic skills in English according to Haryudin \& Argawati (2018) is writing. Writing is a process communication, sharing opinion or ideas through written form. Writing is one of skills that students should be mastered and it is also a difficult subject in the school. It is because students have to produce everyday a text by using English correctly based on the grammatically correctness. According to Scoot (Apsari, 2017) writing activities are directed, writing for communication, not writing for exercise. That means the teachers need to realize that writing activities are an important part of English teaching.

Moreover, writing is very significant for us and frequently used people in daily lives either as individual or group. According to Tarin (Wardani, Nursalim, \& Samsur, 2019) state that writing skills are one productive language skills and expressive used to communicate indirectly and not face to face with the other party. Writing is also taught in formal education considering the importance of having ability and good skill in writing. Relating to the description above, it means that writing is important for our life. In this study the researcher wants to increase students habits especially in created writing recount text using simple past tense in teaching learning process. Recount text is one of kind text that was learnt in eight grade.

Recount text is how to depict past experiences by retelling occasion in the request in which they happened. Recount text also needs to be dominated by students because the material can be implemented for students in daily lives also teaching learning process in the classroom. The goals of recount text is how to retelling story and gives the informing or entertaining for audience. According to Anderson \& Ketty (Wardani et al., 2019) recount text is defined as a 
piece of text that retelling events aimed to provide the people a description of what happened and when it happened.

The important things of recount text in teaching learning process especially in Indonesia is, the students need to learn this subject because recounts are the simplest text type rather than the other genre. So, the students also should be mastered this subject. Relating to the description above, it can be concluding that recount as a piece of text that produce past incident which they happened in order and related in a spesific connection. According to (Rahayu, 2018) as it is known English is taught in Indonesia from junior high to senior high school. Based on the English syllabus, the students are acquired to be competent to write some texts one of them is recount text using simple past tense.

Simple past tense is a part of tenses that an events had occured in the past. The researcher obviously know that simple past tense is used to show an activity that is done in a certain time in past. According to Hartono (Winda, Panggabean, Harputra, \& Harahap, 2019) Simple past tense is how to analysis an event that occured, action, activity or situation that has been finished in the past time in a simple form and also known the moment when the situation or occured has been finished.

Based on the researcher experience when was teaching several classes in junior high school especially eight grade of junior high school. The first impression that the researcher got is, the students was lacking of writing skills and they are do not understand to make a good recount text using simple past tense. Because of that the researcher wanted to unsure the eight grade of junior high school at least can write some sentence correctly. According to Hayati (2017) experience teaching English at the third semester of agriculture students at University of Padang, most of the students had trouble in how to write sentence in the past tense. Yulianti, Nuraeni, \& Parmawati (2019) that students still did not understand about writing.

Many factors can influence that. one of them is the selection of learning models. As Wiriawan (2019) research shows that the selection of direct learning models can improve students' understanding of simple past tense. Besides, in teaching learning process a media also affects. such as using songs when learning in Melalolin, Hartini, \& Mahayanti (2020) research that gives an influence on students' understanding of simple past tense.

But in those research only focused on how to improve students understanding in general without knowing clearly what caused students difficulties in simple past tense. so that the assumption is formed that the trouble faced by male and female students are the same. but of course it's different. According to Amin (2018) states that even in brain structures it differs between male and female which makes women have more communication skills than men.

In addition to these differences, before trying to improve students understanding of simple past tense. The Researcher need to know what difficulties students have in the concept. one of them can be known by analyzing the mistakes produce by students in using the simple past tense.

According to corder (Kristiani, Ginting, \& Purwanto, 2019) there are some types of error: 1. Errors of Omission: Error of omission is the missing of several factors which should exist. 2. Errors of Addition: Error of addition is the increase of several factors which shouldn't exist. 3. Errors of Formation: Error formation is any mistaken form of specific structures or morphemes.4. Errors of Ordering: Error of ordering is the elements which are not put in the proper place. 
Relating to the description above, the researcher want to conduct a research in analyzing students competence in composing especially in recount text using simple past tense based on gender telling their experience about holiday. In order to seek more about how good are the students ability in writing recount text, the research will be analyzing text produced by the students.

\section{METHOD}

This research used qualitative descriptive method as the research methodology. The data would be presented descriptively and the result was in explanation of words form which would be following by data presented in form of tables. Related previous statement (Nurmalasari \& Apsari, 2019) stated that qualitative descriptive method are the least "theoritical" of all of the qualitative approaches to research. In addition, qualitative descriptive studies are the least burdened studies, compared to other qualitative approaches, by a pre-existing theoritical or philosophical commitment. It also supported by Sugiono (2013) that also states that qualitative is a natural object focused method. That was the main instrument of this research, the result focused on the meaning especially rather than generalization.

This population was conducted in MTs Negeri 1 Cimahi. The samples was taken by random technique sampling, the subject of the samples being 26 students of VIII D class. The data of the study were obtained from classroom post-test.

\section{RESULTS AND DISCUSSION}

\section{Results}

After analyzed and testing the 26 students with 16 female students and 10 male of students. The test results are checked and classified based on the type of errors.

Figure 1. Data errors made by students

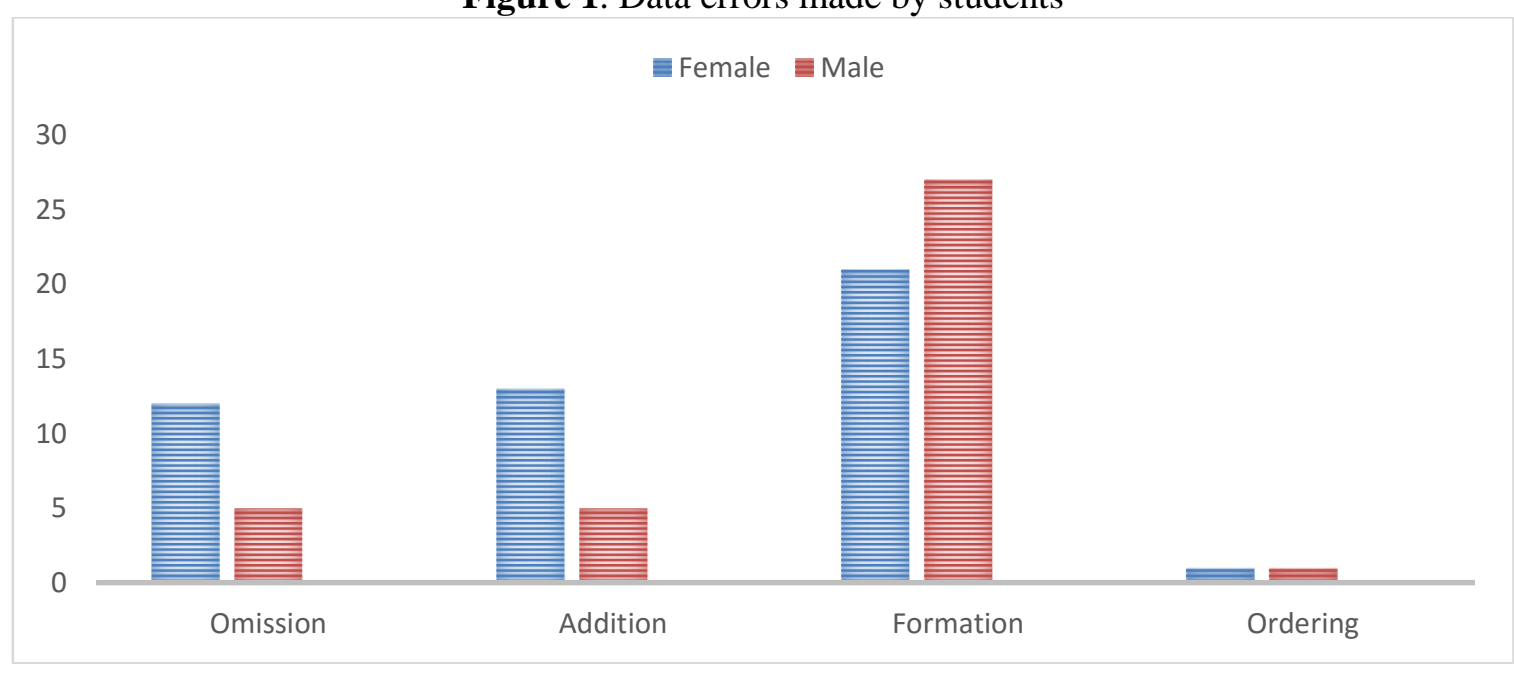

It can be decide that the most mistakes made by all students are mistakes in misformation that is 48 mistakes. Errors in misformation also become the most general errors committed by male students as many as 27 times. Whereas for female students there were 21 misformation errors. 
Based on the description above this data was obtained from the test results of students based on their experience in writing recount text. where there are errors produced by students in the used of simple past tense. This is the result of writing analysis by students at MTs Negeri 1 Cimahi.

\section{Error of misformation}

Misformation errors most often committed by all students. For examples:

1. Last Saturday me and my sister go to gunung padang temple.

2. 20 Desember 2019 me and my family went to the zoo.

Table 1

Correction of Misformation Errors

\begin{tabular}{ll}
\hline \multicolumn{1}{c}{ Error of misformation } & \multicolumn{1}{c}{ Correction } \\
\hline $\begin{array}{l}\text { Last Saturday me and my sister went to } \\
\text { gunung padang temple. }\end{array}$ & $\begin{array}{l}\text { Last Saturday My sister and I went to } \\
\text { gunung padang temple. }\end{array}$ \\
\hline $\begin{array}{l}\text { 20 Desember } 2019 \text { me and my friends go } \\
\text { to the zoo. }\end{array}$ & $\begin{array}{l}\text { 20 Desember my friends and I went to } \\
\text { the zoo. }\end{array}$ \\
\hline
\end{tabular}

Based on the analyzed above it can be decided the errors of students are misformation and simple past tense form. In the pronunciation (a) sentence Last Saturday me and my sister went to gunung padang temple is wrong sentence, because there is misformation of word. So the right sentence is Last Saturday My sister and I went to gunung padang temple. And in the utterance (b) sentence 20 Desember 2019 me and my friends go to the zoo. is wrong sentence, because there is misformation of word. So the right sentence is 20 Desember my friends and I went to the zoo.

\section{Error of Addition}

The second errors made by all students is addition errors. For examples:

1. I ate with rice and egg this evening.

2. He does not to come.

Table 2

Correction of Addition Error

\begin{tabular}{ll}
\hline \multicolumn{1}{c}{ Error of Addition } & \multicolumn{1}{c}{ Correction } \\
\hline I ate with rice and egg this evening. & I ate rice and egg this evening. \\
\hline She does not to come. & She does not come. \\
\hline
\end{tabular}

Based on the analyzed above it can be decided in the utterance (a) sentence I ate with rice and egg this evening. is wrong sentence, because there is addition of word. So the right sentence is I ate rice and egg this evening. And in the utterance (b) sentence She does not to come. is wrong sentence, because there is addition of word. So the right sentence is She does not come.

\section{Error of Omission}

The thrid errors made by all students is Omission errors. For examples:

1. View is very beautiful.

2. He eat banana.

Table 3

Correction of Omission Errors. 


\begin{tabular}{ll}
\hline View is very beautiful. & The view is very beautiful. \\
\hline He eat banana. & He eats an banana. \\
\hline
\end{tabular}

Based on the analyzed above it can be determined in the utterance (a) sentence View is very beautiful. is wrong sentence, because there is omission of word. So the right sentence is The view is very beautiful. And in the utterance (b) sentence He eat banana.. is wrong sentence, because there is omission of word. So the right sentence is He eats an banana.

\section{Error of Misordering}

The fourth errors made by all students is misordering errors. For examples:

1. What you are looking for.

2. He don't know what is holiday.

Table 4

Correction of Misordering Errors

\begin{tabular}{ll}
\hline \multicolumn{1}{c}{ Error of Misordering } & \multicolumn{1}{c}{ Correction } \\
\hline What you are looking for. & What are you looking for. \\
\hline He don't know what is holiday. & He doesn't know what holiday is. \\
\hline
\end{tabular}

Based on the analyzed above it can be decided in the utterance (a) sentence What you are looking for. is wrong sentence, because there is misordering of word. So the right sentence is What are you looking for. And in the utterance (b) sentence He don't know what is holiday. is wrong sentence, because there is misordering of word. So the right sentence is He doesn't know what holiday is.

\section{Discussion}

After analyzed the data from students it can be decided that the most errors produced by students in the recount text are errors in the misformation process. The errors made by female there are 12 errors of omission, 13 errors in addition, 21 errors in misformation and 1 errors in misordering. while the errors are made by male there are 5 errors of omission, 5 errors in addition, 27 errors in misformation and 1 errors in misordering.

\section{CONCLUSION}

After the writer analyzed the data from students MTs Negeri 1 Cimahi. It can be decided that the most errors made by all students in writing recount text based on gender are mistakes in misformation that is 48 Errors. Errors in misformation also become the most common errors committed by male students as many 27 times. Whereas for female students there were 21 misformation errors. From this research it can be decided that the most errors made by female and male are errors in the way of misformation because students lack understanding of how to make stories in recount text using simple past tense.

\section{ACKNOWLEDGMENTS}

Alhamdulillahirabil'alamin, the researcher expressed the highest gratitude to Allah Subhanahuwata'ala for blessings, opportunity, and also health to completed this journal entitled An analysis of writing recount text based on gender. In arrange this research, many people have provided motivation, advice, and support for the researchers. 
Finally, the researcher appreciate and say thanks in advance first, the deepest appreciate given to beloved parents, for endless love, prayer, and support. Also thanks to Mr. Acep Haryudin M.Pd who was support and help to finished this articel. The researcher fell very grateful to have some close friends who always support to finishing the research. This articel is far from perfect, but it is expected to be useful not only for researchers, but also for readers. Hopefully the readers will understand with the explanation in this articel. And this articel it will be useful not only for the writer, but also for the readers. For this reason, constructive thoughtful suggestion and critics are welcomed.

\section{REFERENCES}

Amin, M. S. (2018). Perbedaan Struktur Otak Dan Perilaku Belajar Antara Pria Dan Wanita; Eksplanasi Dalam Sudut Pandang Neuro Sains Dan Filsafat. Jurnal Filsafat Indonesia, 1(1), 38-43.

Apsari, Y. (2017). The Use Of Picture Series In Teaching Writing Recount Text. Eltin Journal, Journal Of English Language Teaching In Indonesia, 5(2), 51. Https://Doi.Org/10.22460/Eltin.V5i2.P51-56

Haryudin, A., \& Argawati, Ningtyas Orilina. (2018). Lesson Study To Improve Student English Grammar Mastery Using Jigsaw Technique To The Third Semester Students Of Ikip Siliwangi. Indonesian Efl Journal, $4(1), \quad 56$. Https://Doi.Org/10.25134/Ieflj.V4i1.798.Received

Hayati, A. (2017). Agriculture Students' Ability To Write Past Tense At Taman Siswa University Of Padang. Al-Ta Lim Journal, 24(1), 47-52. Https://Doi.Org/10.15548/Jt.V24i1.259

Kristiani, H., Ginting, B., \& Purwanto, P. (2019). Error Analysis On Using Simple Past Tense In Writing Recount Text At The Eighth Grade Of Smp Bina Bersaudara 1 Medan. 6(1).

Melalolin, L. M., Hartini, N. M. S. A., \& Mahayanti, N. W. S. (2020). Pemanfaatan Lagu Sebagai Media Pembelajaran Untuk Meningkatkan Pemahaman Tentang Simple Past Tense. Journal For Lesson And Learning Studies, 3(1), 108-119.

Nurmalasari, M., \& Apsari, Y. (2019). Improving Students' Participation In Speaking English Using Snowball Throwing Technique. Project (Professional Journal Of English Education), 2(2), 115. Https://Doi.Org/10.22460/Project.V2i2.P115-121

Rahayu, P. (2018). An Analysis Of Recount Text Writing Composition Of Tenth Grade Senior High School Students. 6, 165-176.

Wardani, R. C., Nursalim, \& Samsur, F. Ramadhani. (2019). Students Ability In Constructing Paragraph Of Recount Text. Interaction: Jurnal Pendidikan Bahasa, 6(1), 32-40. Https://Doi.Org/10.1016/J.Surfcoat.2019.125084

Winda, Y., Panggabean, S., Harputra, Y., \& Harahap, N. (2019). Improving The Students Mastery In Simple Past Tense Through Peer-Editing Technique. 4(1), 14-23.

Wiriawan, I. K. (2019). Implementasi Model Pembelajaran Langsung ( The Direct Instruction Model ) Dalam Upaya Meningkatkan Pemahaman Siswa Terhadap The Simple Past Tense Pada Siswa Kelas Xi Ips 2 Di Sma Jagadhita Amlapura. Prosiding: Stkip Agama Hindu Amlapura, 154-174. Retrieved From Jayapanguspress.Penerbit.Org/Index.Php/Ganaya/Article/Download/359/347

Yulianti, S., Nuraeni, S., \& Parmawati, A. (2019). Improving Students'writing Skill Using Brainswriting Strategy. Project (Professional Journal Of English Education), 2(5), 714721. https://Doi.Org/10.22460/Project.V2i5.P714-721 